DOI https://doi.org/10.30525/978-9934-26-073-5-1-72

\title{
LINGUISTIC PRINCIPLES OF BRAND RESEARCH
}

\author{
Ushchapovska I. V. \\ Candidate of Philological Sciences, \\ Senior Lecturer at the Germanic Languages Department \\ Sumy State University \\ Sumy, Ukraine
}

The term «brand» is associated primarily with marketing. However, recently there has been an expansion of the meaning boundaries of the word, which is widely used in other areas of human activity, which allows distinguishing political, cultural, religious brands, etc. Current approaches to the brand study reveal its communicative essence and indicate the possibility of linguistic analysis. The brand is a socio-cultural phenomenon embodied in a sign and symbolic form mentally perceived by its target audience due to stable positive associations caused by the convergence of verbal and nonverbal elements of communication [5, p. 42].

In the brand communication paradigm, the brand acts as a source of information about the company or its products (sender), which transmits this information to the consumer (receiver) through the brand language - a common system of symbols or code. The communicative chain can be presented as the interaction of the sender and the recipient, where the sender creates meanings, encodes them into signs, forms a message from the signs. Moreover, the recipient accordingly decodes the message signs, applying his experience, value system, knowledge, and so on.

From the perspective of semiotic discourse, the brand is a certain sign endowed with meanings, together with the person who perceives it [2, p. 220]. The brand is at the intersection of the discourses of brand owners, manufacturers, and consumers, as well as various groups of professionals, each providing his or her definition of the brand in particular and its concept in general. Brands are semiotic systems that create value in the market by differentiating competitors, forming emotional connections with consumers, and combining the company's symbolic values with contemporary cultural trends. The brand is a sign system that has almost nothing to do with the ease of use of the product but is so integrated into its marketing and promotion that over time it becomes an integral semiotic feature of the product [6, p. 59].

A particular type of communication in the modern globalized communicative environment is branding as it allows promoting the brand and, 
as a result, increases consumer interest and expands the target audience without any geographical restrictions [1, p. 33]. Branding as a mechanism of promotion is formed largely through language tools that allow establishing a connection between the brand and the receivers. Brand attributes, such as name, logo, slogan, color combinations, and corporate fonts are the core elements of modern communication, which makes it possible to consider branding a communication technology. Special attention should be paid to the convergence of verbal and non-verbal elements in the brand language.

The brand is a sign in terms of the semiotics of the word, and branding is a sign process or semiosis. At cognitive and discursive levels, branding attracts both individuals and social communities i.e. target groups of the market or its segments. From a semiotic point of view, a non-branded product could not generate and maintain imagery and experience, except for immediate functional benefits. Brands shift the language by which consumers perceive and talk about products, they enrich that language by obtaining ideas, images, and even fears from culture as a common reservoir of meanings, as well as by actively participating in groups, events, and activities directly related to brands [7, p. 63-64].

Current approaches in the brand study reveal its communicative essence and indicate the possibility of linguistic interpretation and modeling of discursive branding practices. A new type of discourse is added to the objects of linguistics study - the brand discourse. Brand communication is a discursive formation that establishes specific personalized communicative relations of the company with its consumers to form a loyal attitude of the target audience to goods and services [4, p. 82].

In modern society, the brand acts as a mental unit of the linguistic worldview, accumulating various associative images, concepts, ideas, attitudes, evaluations, and so on. Brand semantics is formed in the human mind, providing an emotional connection between the linguistic perception of the brand and its semantic functioning. Brands occupy a place of functional expediency in the minds of society, creating a single set of associations and a holistic image. The pragmatic meaning of the brand is revealed through the processes and images that are engraved in the mind, but, unlike the semantic (which conveys meaning through words and their combinations), is formed in the context of language use [3, p. 3].

Thus, the linguistic interpretation of the brand is possible due to its integrative communicative semantic and pragmatic essence. The brand is a socio-cultural phenomenon embodied in a symbolic form. It exists in the minds of its target audience due to persistent positive associations caused by the convergence of verbal and non-verbal elements of communication. Brand 
semantics provides an emotional connection between the linguistic perception of the brand and its semantic load. The brand is dialectical integrity of its name, attributes, values, promises, positioning, identity, mythology, functional, spiritual, and emotional benefits that are significant for the consumer, meet his needs, and are fixed in his mind. This integrative essence is the basis of the linguistic research of the brand. The integrative semantic and pragmatic functions of the brand are realized within the framework of brand communication.

\section{References:}

1. Bilyuk I. L. Brendynh mist $\mathrm{v}$ anhlomovnomu komunikatyvnomu prostori: verbalna ta vizualna skladovi [City branding in the English communicative environment: verbal and visual components]: dys. ... kand. filol. nauk : 10.02.04. Zhytomyr, 2016. 238 p.

2. Vardavanyan S. I., Vardavanyan V. A. Psykholohichni aspekty formuvannya brendu terytoriy [Psychological aspects of the brand formation of territories]. Visnyk Chernivets'koho torhovel'no-ekonomichnoho instytutu. Ekonomichni nauky. 2013. Vyp. 4. Pp. 218-223.

3. Medvedeva A. A., Morgunova A. A. Naimenovaniya brendov v sovremennom angliyskom yazyke: strukturno-semanticheskiye osobennosti [Brand names in modern English: structural and semantic features]. Gumanitarnyye i sotsialnyye nauki. 2016. № 2. Pp. 51-60.

4. Romashova I. V. Lingvisticheskiy analiz brend-kommunikatsii [Linguistic analysis of brand communication]. Nauchnyy dialog. 2016. № 6 (54). Pp. 80-93.

5. Ushchapovska I. V. Strukturno-semantychni, sotsiolinhvalni ta prahmatychni parametry movy brendu: multymodalnyy pidkhid (na materiali anhlomovnykh brendiv kavy) [Structural and semantic, socio-lingual, and pragmatic parameters of the brand language: multimodal approach (case study: English-language coffee brands)] : dys. ... kand. filol. nauk : 10.02.04. Zaporizhzhya, $2020.258 \mathrm{p}$.

6. Swales J., Rogers P. S. Discourse and the projection of corporate culture: the mission statement. Discourse \& Society. 1995. P. 223-242

7. Trendafilov D. From artifacts to experiences: brands in the era of prosumeration. Public Journal of Semiotics. 2016.7 (1). Pp. 59-79 